\title{
A DOUTRINA DO DEVIDO PROCESSO LEGAL SUBSTANTIVO E A (IN)COMPLETUDE DA ORDEM JURÍDICA
}

\section{Davi Marcucci Pracucho}

Mestrando em Direito, com área de concentração em Direitos Humanos, pela Fundação Universidade Federal de Mato Grosso do Sul (UFMS). Bacharel em Direito pela Universidade de São Paulo (USP) - Faculdade de Direito do Largo São Francisco. Procurador da República - membro do Ministério Público Federal. Ex-defensor Público no Estado de São Paulo.pracucho@gmail.com

\section{Resumo}

0 propósito deste artigo é investigar se existe relação necessária entre a incompletude da ordem jurídica e a doutrina do devido processo legal substantivo, buscando contribuir para 0 esclarecimento das condições de aplicação e do papel dessa doutrina. Para tanto, emprega-se o método dedutivo, estabelecendo-se as premissas do raciocínio de forma descritiva e com suporte em bibliografia autorizada. Ao final, em termos de resultados, além de não se verificar a suposta relação necessária, observa-se que os desenvolvimentos recentes do pensamento jurídico não infirmam, antes confirmam, o acerto daquela doutrina, na sua essência.

\section{Palavras-chave:}

Devido processo legal substantivo. Ordem jurídica. Incompletude.

\section{THE SUBSTANTIVE DUE PROCESS OF LAW DOCTRINE AND THE (IN)COMPLETENESS OF THE LEGAL ORDER}

\section{Abstract \\ The purpose of this article is to investigate if there is a necessary relationship between the incompleteness of the legal order and the substantive due process of law doctrine, seeking to contribute to the clarification of the conditions of application and the role of this doctrine. For that, the deductive method is used, establishing the premises of the reasoning in a descriptive


way and with support in authorized bibliography. In the end, in terms of results, in addition to not verifying the supposed necessary relation, it is observed that the recent developments of legal thought do not invalidate, but confirm, the correctness of that doctrine, in its essence.

\section{Keywords:}

Substantive due process of law. Legal order. Incompleteness.

Recebido em: 28/2/2017

Aceito em: 13/10/2017

\section{Sumário:}

1 Notas introdutórias. 2 Sucinta exposição da doutrina do devido processo legal substantivo. 3 Algumas críticas à doutrina do devido processo legal substantivo. 4 A questão da (in) completude da ordem jurídica. 5 Devido processo legal substantivo e (in)completude da ordem jurídica. 6 Considerações finais. 7 Referências. 


\section{NOTAS INTRODUTÓRIAS}

A doutrina do devido processo legal substantivo não encontra base textual expressa na Constituição dos Estados Unidos da América, país no qual se disseminou inicialmente, nem na Constituição brasileira, apesar de também ter encontrado aceitação no Brasil, ainda que não com o mesmo desenvolvimento dado pelos juristas norte-americanos.

Uma possível explicação para o recurso à doutrina do devido processo legal substantivo, a despeito da ausência da sua previsão pelo legislador, é a incompletude da ordem jurídica. Vale dizer: sendo o Direito incompleto, não regulando todas as situações, é necessário recorrer a outros elementos para que nada fique desprovido de solução. O devido processo substantivo seria um desses elementos.

Diante disso, a indagação que se propõe é: Existe uma relação necessária entre a exigência do devido processo legal substantivo, não prevista pelo legislador, e a incompletude da ordem jurídica?

A investigação envolve um itinerário que parte de uma sucinta exposiçấo da doutrina do devido processo legal substantivo, incluindo os seus traços essenciais e algumas críticas que lhe são dirigidas, passando pela colocação da questão da (in) completude da ordem jurídica e culminando com a verificação, então, da relação existente entre aquela doutrina e a questão colocada.

A aproximação dos temas é feita de forma dedutiva, com suporte em pesquisa bibliográfica.

\section{SUCINTA EXPOSIÇÃO DA DOUTRINA DO DEVIDO PROCESSO LEGAL SUBSTANTIVO}

A doutrina do devido processo legal substantivo (em inglês: substantive due process) é, em poucas palavras, a doutrina segundo a qual o chamado princípio do devido processo legal não é atendido apenas por meio da observância de determinados procedimentos legais (procedural due process), exigindo, ademais, que a norma jurídica a ser aplicada seja razoável, justa. E, tratando-se o devido processo legal de 
um princípio constitucional, pode o poder Judiciário, com base nessa doutrina, declarar a inconstitucionalidade de uma norma, com a consequência de a considerar nula e de nenhum efeito (FERREIRA FILHO, 2016).

Assim é que, p. ex., para que seja conforme o devido processo legal, não basta à imposiçấo de uma determinada penalidade que ela tenha sido prevista em uma lei editada por meio dos devidos trâmites constitucionais. Não basta, outrossim, que tenha sido aplicada pela autoridade administrativa com atribuição para tanto, valendo-se do procedimento legal correto. Nem, ainda, que tenha sido executada pelo juízo competente e observados o contraditório e a ampla defesa. Nada disso é suficiente para a regularidade do ato se a penalidade em si for desarrazoada, injusta, pois violado estaria, nessa hipótese, o devido processo legal substantivo. Sendo a substância (o conteúdo) do ato indevida (arbitrária, injusta), não há processo, procedimento, que possa legitimá-la.

As linhas anteriores trazem somente uma sucinta simplificação introdutória do que vem a ser a doutrina do devido processo legal substantivo. Cumpre, doravante, avançar um pouco mais no rico substrato desse construto.

A expressão inglesa supracitada - substantive due process - dá conta da origem da doutrina, que se formou em torno do denominado princípio do devido processo legal.

Pereira (2006) relata que o princípio do devido processo legal foi pela primeira vez positivado no sistema jurídico do common law, em 1215, na Magna Carta, com a notória expressão law of the land (na verdade, entáo em latim: per legem terrae; em traduçấo literal: "direito da terra"). Em 1354, na chamada Lei de Westminster das Liberdades de Londres (Statute of Westminster of the Liberties of London), a expressão foi substituída por due process of law, repetida no The Petition of Right (1627), no Habeas Corpus Act (1640), incorporada à Constituição norte-americana (1791) e mantida até hoje.

Informa o autor, ademais, que a compreensão do due process of law para além da observância de procedimentos e formas legais, embora tenha surgido na Inglaterra, lá não teve difusão. Foi nos Estados Unidos da América, a partir da supramencionada previsão constitucional (especificamente, emendas 5/1791 e 14/1868), que, na segunda metade do século 19, ganhou força um movimento 
doutrinário e jurisprudencial sustentando o alcance substantivo do due process, com capacidade para obstar açóes estatais arbitrárias, desarrazoadas ou injustas, ainda que pautadas em procedimentos impecáveis, com aptidão, ainda, para propiciar a atualização hermenêutica da Constituição, a despeito de inalterado o seu texto.

Conforme anotam Souza Neto e Sarmento (2012), inicialmente a doutrina foi invocada para a tutela de direitos patrimoniais e econômicos, em um contexto de liberalismo econômico e absenteísmo estatal, em virtude de normas que intervinham nas relaçôes econômicas e sociais, ainda que com o escopo de proteger a parte mais fraca contra abusos. Trata-se do período conhecido como Era de Lochner, em referência ao caso Lochner v. New York, julgado pela Suprema Corte norte-americana em 1905, ocasiáo em que o Tribunal invalidou a lei do Estado de Nova York que havia estabelecido a jornada máxima de trabalho para os padeiros em 10 horas diárias e 60 semanais. $\mathrm{O}$ fundamento essencial, na decisão do caso, foi a então considerada indevida interferência do Estado na autonomia contratual.

No final da década de 30, entretanto - prosseguem os autores - em meio à instituição do New Deal, plano econômico fortemente intervencionista levado a efeito pelo popular presidente Franklin Roosevelt com o objetivo de resgatar o país da depressão econômica, a Corte alterou a sua orientação, passando a admitir a interferência estatal para a proteção de liberdades civis não econômicas, desde que não absolutamente desarrazoada. Nesse sentido, p. ex., o caso West Coast Hotel Co. v. Parrish, julgado em 1937 e no qual se assentou que a liberdade de contratar pode ser limitada se tal limitação for razoável no seu conteúdo e adotada em prol da comunidade contra males que ameacem a saúde, a segurança, a moralidade ou o bem-estar das pessoas.

Nessa nova fase, a doutrina do devido processo legal substantivo, segundo Souza Neto e Sarmento, embasou um maior ativismo judicial. Quer dizer: maior intervenção do poder Judiciário no mérito de certas valoraçóes legislativas ou administrativas (BARROSO, 1996), o que se concretiza por meio da (i) aplicação direta da Constituição a situaçóes não expressamente previstas no seu texto e independente de ato do legislador ordinário; (ii) declaraçáo de inconstitucionalidade de atos legislativos com base em critérios menos rígidos do que a patente violação da Constituição ou (iii) imposição de condutas, comissivas ou omissivas, ao poder público, em especial em matéria de políticas públicas (BARROSO, 2013). 
Em termos de conteúdo doutrinário propriamente dito, tem-se que a teoria do devido processo legal substantivo surgiu a partir da concepção visionária do jurista inglês Edward Coke, que indagou se, observados os trâmites legais, o legislador tudo poderia - ao que respondeu: não, argumentando existirem limites no próprio Direito e, além, na razão - questáo fulcral da qual se valeram a doutrina norte-americana e, posteriormente, John Marshall, na Suprema Corte dos Estados Unidos da América, para propugnar a nulidade de atos do Parlamento que subvertessem o direito (especialmente à vida, à liberdade e à propriedade), a razoabilidade ou a justiça, ao mesmo tempo em que lançaram, com isso, as bases da judicial review, vale dizer, a possibilidade de as Cortes controlarem a validade de atos legislativos, i.e., o controle de constitucionalidade (PEREIRA, 2006).

Pode-se afirmar, desse modo, ainda com base em Pereira (2006), que constituem pressupostos teóricos da doutrina do devido processo legal substantivo a supremacia da Constituição e a possibilidade de controle dos poderes instituídos pelo poder Judiciário, a chamada supremacia judicial. E que, sobre tais pressupostos, desenvolveram-se ideias tendentes a balizar os comportamentos estatais para além do mero respeito aos procedimentos e às formas, a exemplo das noçóes de que existem limitaçôes implícitas ao poder (e mesmo ao princípio da maioria), bem assim direitos fundamentais implícitos; e isso não em um cenário normativo estático, mas sim compreendendo-se a Constituição como um fenômeno vivo, evolutivo na direção das novas exigências sociais, revelando-se papel do poder Judiciário atuar ativamente na atualização do sentido do texto constitucional - embora e ainda que sem a modificação do texto em si.

Entre os diversos exemplos citados por Pereira de aplicação do substantive due process pela Suprema Corte estadunidense, estão os casos Roe v. Wade (1973), em que foi reconhecido às mulheres o direito de interromper a gravidez (aborto), e Lawrence v. Texas (2003), no qual o Tribunal reconheceu o direito de pessoas adultas voluntariamente se engajarem em condutas homossexuais. Em ambos os casos não havia base textual expressa na Constituição para a decisão, valendo-se a Corte da cláusula do due process na sua dimensão substantiva.

O autor destaca, de mais a mais, que a aplicação da doutrina pela Suprema Corte norte-americana não teve uma evolução estritamente linear. Faz-se importante sublinhar aqui, então, que, a despeito das ditas fases, antes assinaladas, houve idas 
e vindas no manejo do substantive due process, ora empregado mediante critérios restritos, ora utilizado de forma mais elástica, a depender da conjuntura histórica e dos direitos em questáo.

Independentemente, entretanto, dos denominados padróes de escrutinio do substantive due process - tema com aptidão para render um estudo à parte - importa ter em mente, para os propósitos deste trabalho, o traço essencial da doutrina, qual seja, a referência a critérios materiais não necessariamente contidos de forma expressa no texto constitucional, tratando-se de, "como salienta a doutrina norte-americana, uma value-oriented theory ["teoria orientada por valores", em tradução livre], pois o processo devido deve ser materialmente informado pelos princípios da justiça” (CANOTILHO, 2003, p. 494).

A dimensão substantiva do due process of law tem sido aceita, em geral, pela doutrina brasileira, sendo associada aos conceitos de razoabilidade (SOUZA NETO; SARMENTO, 2012; BARROSO, 2013) ou proporcionalidade (MENDES, 2012), ou ao reconhecimento de direitos fundamentais implícitos, complementando o princípio da dignidade da pessoa, bem como a efetividade do processo e proteção judicial efetiva (MATTOS, 2008).

Na jurisprudência do Supremo Tribunal Federal encontram-se precedentes relacionando a dimensão material do devido processo legal, ao mesmo tempo, à razoabilidade e à proporcionalidade, a exemplo da decisão nas açôes diretas de inconstitucionalidade 173 e 394, julgadas em conjunto em 25 de setembro de 2008 (BRASIL, 2009).

De todo modo, também em relação à doutrina e prática brasileiras vale a observação de que as discussóes em torno dos parâmetros de aplicação da dimensão substantiva do due process não afetam a ideia essencial, recortada para os fins do presente ensaio, de que se trata, o devido processo legal, de uma norma jurídica cujo conteúdo transborda a fixaçáo de procedimentos corretos, obstando - por intermédio de referências valorativas - incorreçôes materiais arbitrárias ou desarrazoadas, havendo, aí, uma conexão com os princípios da Justiça. 


\section{ALGUMAS CRÍTICAS À DOUTRINA DO DEVIDO PROCESSO LEGAL SUBSTANTIVO}

A doutrina do devido processo legal substantivo, como qualquer doutrina ou tese jurídica, não é imune a críticas.

As críticas existem, primeiramente - como sói ser - entre os juristas norte-americanos, vale dizer, no próprio ambiente de origem da doutrina.

Ali, é antiga e bem conhecida a objeção de que, a pretexto de assegurar uma correção material, os Tribunais, valendo-se do substantive due process, acabam substituindo as decisôes legislativas pelas suas valoraçóes. Outrossim, tem-se a percuciente observação de Edward S. Corwin, para quem, com a disseminação da doutrina, o controle judicial deixou de ter limites definidos e definíveis (PEREIRA, 2006).

Bastante representativo dos críticos é Ely (2010), que, na sua influente obra Democracy and distrust: a theory of judicial review (Democracia e desconfiança: uma teoria do controle judicial de constitucionalidade), publicada em 1980 - na qual busca construir uma terceira via entre interpretativismo (fidelidade ao texto da Constituição, bem como às intençôes dos seus autores) e não interpretativismo (possibilidade de reavaliação/atualização do sentido do texto constitucional) - sustenta não ser histórica nem logicamente viável extrair, a partir da cláusula do devido processo inserta na $5^{\mathrm{a}}$ e na $14^{\mathrm{a}}$ emenda, algo diferente da dimensão procedimental.

Argumenta que, naqueles textos, o que é devido é o processo, não havendo fundamento histórico para que se compreenda algo diferente do que sempre se entendeu como processo: grosso modo, um procedimento. De modo que falar em devido processo substancial é uma contradição em termos, assim como "brancura preta"; ao mesmo tempo em que é redundante a formulação "devido processo procedimental". Quer dizer com isso o autor, veja-se, que não existe base normativa para o que se designa devido processo legal substantivo.

Avançando à aplicação da doutrina, Ely assinala ser essencialmente vazia a exigência de que o Estado se comporte de modo "racional", além do que semelhante teoria amplia em demasia as hipóteses de atuação judicial e dá azo ao descrédito das suas decisóes. 
No Brasil, Mariotti (2008) alerta para a necessidade de cautela na aplicação da doutrina do substantive due process ao Direito pátrio, devendo-se, sem que isso signifique olvidar o seu sentido original, situá-la no contexto da Constituição analítica de um Estado que se vincula à família do Direito romano-germânico.

Trilhando esse caminho, asseveram Marinoni e Mitidiero (2013) que, no Direito brasileiro, inexiste a necessidade de pensar o devido processo legal para além da sua dimensão processual. Isso porque - argumentam com suporte nas liçóes de Humberto Ávila - os deveres de proporcionalidade e razoabilidade não decorrem de uma suposta dimensão substantiva do devido processo, e sim dos princípios da liberdade e igualdade, posiçóes jurídicas que devem ser exercidas de forma proporcional e razoável no Estado Constitucional. Ademais, prosseguem, tampouco é necessário recorrer ao substantive due process para tutelar direitos fundamentais não explícitos, porquanto a Constituição brasileira conta com um catálogo aberto de direitos fundamentais (artigo $5^{\circ}, \$ 2^{\circ}$ ).

Não é escopo deste trabalho reforçar ou refutar as críticas à doutrina do devido processo legal substantivo. Por essa razão a exposição, neste tópico, não pretende ser exaustiva. Acredita-se que, até este ponto, desenvolveu-se o suficiente para a fixação da ideia de que, para os críticos da teoria, ela é desnecessária, por ser supérflua, prejudicial ou até mesmo contrária à ordem jurídica.

Essa ideia, juntamente à ideia principal do tópico anterior (conexão do due process com elementos de correçẫo material: valores e princípios da justiça), é retomada adiante, buscando-se cotejar ambas com a questáo da (in)completude da ordem jurídica, tema da próxima seção.

\section{A QUESTÃO DA (IN)COMPLETUDE DA ORDEM JURÍDICA}

Ensina Bobbio (1995) que a questão aqui exposta como (in) completude da ordem jurídica - na sua formulação típica: lacunas do direito - remonta às concepçôes jusfilosóficas do racionalismo liberal do século 18, que teorizaram sobre o dito dogma da onipotência do legislador (monopolização da produção jurídica por parte do legislador), defendendo Montesquieu, p. ex., que a decisão de um juiz deve ser 
uma reprodução fiel da lei (em observância à separação dos poderes), e Beccaria, a seu turno, que o juiz, ao aplicar uma lei, dever proceder como aquele que deduz a conclusão de um silogismo (teoria do silogismo).

O autor esclarece que, mesmo nesse contexto, os escritores da época admitiam a possibilidade de existirem casos nos quais determinadas relaçóes ou situaçóes não foram reguladas pelo legislador, devendo-se recorrer, então, ao Direito natural - aplicação subsidiária do Direito natural. Uma solução coerente, observa o filósofo de Turim, para quem o Direito positivo se funda no ius naturale.

Essa concepção do Direito natural como instrumento para a colmatação as lacunas do Direito positivo - prossegue o mestre italiano - sobreviveu até o período das codificaçóes e, mais do que isso, teve significativa propagaçáo durante aquele período.

Como não poderia deixar de ser, todavia, semelhante tese foi fortemente combatida pelos juspositivistas, para os quais, tomando-se emprestada de Bobbio $(1995,1999)$ a formulaçáo mais emblemática da teoria, o Direito positivo constitui um ordenamento com três características principais: unidade, coerência e completude. Unidade como positivaçáo direta ou indireta por uma mesma autoridade, com idêntico fundamento último de validade. Coerência como a impossibilidade lógica de coexistirem igualmente válidas, em um mesmo ordenamento jurídico, normas incompatíveis entre si. E completude, por fim - considerada por Bobbio o "coraçáo do coração" do positivismo jurídico - no sentido de que, perante um ordenamento jurídico qualquer, não é possível que exista uma conduta ou situação não regulada, vale dizer, que não seja permitida, proibida ou determinada, expressa ou implicitamente.

Uma observação importante do professor de Turim: quando se fala em completude do ordenamento jurídico, está-se a pensar na lei, visto que, de outro modo, a questão não se coloca, se por Direito entender-se as normas que derivam de qualquer fonte, incluindo a judiciária, pois aos juízes, em regra, aplica-se a vedação do non liquet, tendo o dever de proferir uma decisão ainda que em meio à lacunosidade das fontes estatais. 
Retomando o curso da exposiçáo, bem se vê em Kelsen (1998, 2005), um dos expoentes máximos do juspositivismo, a tese de que a aplicação do Direito é sempre logicamente possível (afinal, perante a lei, uma conduta só pode ser lícita ou ilícita), não se podendo sustentar, do ponto de vista estritamente racional, a existência de lacunas. Para ele, o que verdadeiramente ocorre é que os órgãos aplicadores do Direito acabam presumindo as ditas lacunas quando o resultado da incidência de uma determinada norma jurídica é considerado insatisfatório à luz da política jurídica, sendo, desse modo, afastado em prol de outra solução, esta invocada como a acertada, equitativa, etc. - de todo modo, a solução desejável.

Indo além, o jurista de Praga, na sua Teoria Pura do Direito, expressa que, descrevendo-se o fenômeno jurídico como ele realmente é e funciona (neutralidade científica), tem-se ser inevitável o poder de um tribunal decidir um caso segundo a sua livre apreciação por considerar ética ou politicamente insatisfatória a aplicação da ordem jurídica vigente. E, nesse cenário, advoga que as chamadas normas de integração (aludindo à analogia, aos costumes ou princípios gerais, e.g.) podem representar nada mais do que o reconhecimento do próprio legislador da possibilidade de as normas jurídicas produzirem resultados indesejáveis, assim como podem significar justamente uma tentativa de limitar ou balizar aquele poder de apreciação política das cortes.

A teoria kelseniana sobre as lacunas apoia-se, fundamentalmente, no argumento da norma geral exclusiva, segundo o qual, em suma, diante de uma ordem jurídica, o que não é proibido/regulado é permitido (mais precisamente: constitui uma norma geral de toda ordem jurídica que o que não está incluído em uma determinada regulação está excluído dela - daí norma geral exclusiva), pressupondo-se ser sempre identificável a situação de permissáo ou proibição.

Bobbio (1999) aponta o ponto fraco do principal argumento de Kelsen (originalmente, na verdade, da lavra de Zitelmann): a existência, na ordem jurídica, de normas gerais inclusivas, que, operando de forma oposta ao binômio normas particulares inclusivas - norma geral exclusiva, determinam que casos não compreendidos em uma norma particular, mas semelhantes àqueles compreendidos, sejam regulados de maneira idêntica. Ocorre que o ordenamento jurídico, em geral, nada 
diz sobre como identificar casos parecidos, cabendo ao intérprete, ao fim e ao cabo, de alguma forma verificar se incide a norma geral exclusiva (caso diferente, não previsto) ou a norma geral inclusiva (caso parecido, previsto).

Assim é que conclui o filósofo italiano: tecnicamente, lacuna há, no ordenamento jurídico, não na ausência de norma para um determinado caso (o que jamais ocorre), e sim na falta de critério para a escolha de qual das duas regras gerais, a exclusiva ou a inclusiva, deve ser aplicada. Revela isso, de todo modo, arremata, a incompletude do ordenamento jurídico.

Essa espécie de lacuna, situada no interior do sistema, ou do sistema em si, é designada por Bobbio lacuna própria, em contraposição às lacunas impróprias ou ideológicas, estas decorrentes da comparação de um sistema real com um sistema ideal. Nessa hipótese, o que se tem é a detecção da falta não de uma norma, uma solução, mas de uma solução satisfatória - ideia similar à trabalhada por Kelsen, suprarreferida.

Também anota a incompletude do Direito positivo Engisch (2014, p. 309), para quem "não existe uma plenitude (fechamento) da ordem jurídica que seja lógica e teorético-juridicamente necessária”; sem prejuízo, contudo, de que a plenitude da ordem jurídica possa ser mantida como uma ideia regulativa, i.e., como - citando Kant - um princípio da razão que não aceita o que no objeto nos é apresentado como um dado em si, postulando o que deve acontecer.

Diferentemente, porém, o autor alemão situa as lacunas, ao lado do que denomina incorreçôes, sob o conceito comum deficiências do Direito. Nas lacunas, o juiz é chamado a aplicar um direito praeter legem, quer dizer, completando a ordem positiva. Já nas incorreçôes, a atuação do magistrado opera-se contra legem, corrigendi causa (na expressão de Bobbio, foi visto, haveria, aqui, uma hipótese de lacuna ideológica). Destaca ainda o professor catedrático de Munique: a fronteira entre o preenchimento de lacunas e a correção jurídica nem sempre é nítida e segura.

Observa, ademais, que a maior ou menor extensão do conceito de lacuna é uma questão terminológica e que, de toda sorte, a linha de fronteira entre a aplicação do Direito secundum legem e o preenchimento de lacunas praeter legem torna-se pouco nítida quando se está diante da incidência de cláusulas discricionárias, cláusulas gerais, conceitos normativos indeterminados e princípios gerais do Direito. Nesses 
casos, para Engish, o que se tem, em verdade, é apenas um afrouxamento planejado da vinculação legal, possibilitando o ajustamento da decisão às circunstâncias particulares do caso concreto e às concepçóes variáveis da comunidade jurídica.

Antes de finalizar a presente seção, cumpre registrar, outrossim, as igualmente valiosas liçóes de Perelman (2005): tratando-se a lacuna do silêncio da lei, observe-se que esse silêncio só pode ser constatado depois da interpretaçáo da lei; e isso tanto no contexto das outras normas jurídicas quanto da situação de fato. De tal modo que, frequentemente, havendo desacordo sobre a interpretação, há, também, desacordo quanto a tratar-se de lacuna praeter ou contra legem. Dito de outro modo: respectivamente, lacuna da lei ou erro do legislador; lacuna imanente ou transcendente. Distinçóes que, assinala o autor, conquanto claras na teoria, são deveras controvertidas na prática.

Da relação entre lacuna e interpretaçáo resulta que, na visão do jusfilósofo de Varsóvia, muito amiúde teorias jurídicas como a do abuso de poder, da fraude à lei, da ordem pública internacional, entre outras, permitem, a um só tempo, descobrir uma lacuna e preenchê-la, desse modo limitando a aplicação de textos legais - o que, anota, alguns autores qualificam de falsa lacuna, decorrente da incompatibilidade entre um texto legal e as suas consequências inadmissíveis, porque contrárias à equidade.

O professor da Universidade de Bruxelas conclui afirmando que o problema das lacunas surge, em geral, por ocasiáo de um conflito entre a letra e o espírito da lei ou do sistema, devendo o juiz, nessa hipótese, conceder primazia aos valores que o próprio legislador considera mais importantes. Para tanto, deve ir além da letra da lei, ou mesmo opor-se a ela, observando-se que esse processo náo envolve uma técnica uniforme para todos os casos. De todo modo, o papel ativo do magistrado é necessário porque a lei não é a única fonte do Direito. E pode a lei, como dito, levar a consequências inadmissíveis. Por outro lado - ressalva - não pode o juiz estatuir de forma arbitrária, devendo motivar suas sentenças por meio da lógica jurídica, em conformidade com o espírito do Direito, extraindo novas premissas a partir dos textos existentes. 


\section{DEVIDO PROCESSO LEGAL SUBSTANTIVO E (IN)COMPLETUDE DA ORDEM JURÍDICA}

As ponderaçôes de Engish e Perelman, sucintamente delineadas ao final da seção precedente, mostram-se uma espécie de prenúncio da atual quadra da Filosofia do Direito.

Nos dias atuais, a questão da completude ou incompletude da ordem jurídica, em meio a uma gama de conceitos normativos fluidos (Engish), bem assim ao caráter hermêutico-lógico-argumentativo da identificação do Direito (Perelman), cedeu espaço a outro problema. Sobretudo, com a superação do modelo de regras e a ascensão teórica dos princípios (DOWRKIN, 2002; ALEXY, 2011), Fala-se, hoje, no problema da (in) determinabilidade do Direito, discutindo-se o papel dos juízes e tribunais diante dele (STRECK, 2014).

Com efeito, do assentar a realidade ou influência jurídica dos princípios, normas de vocação expansiva, segue restrito ou mesmo nenhum lugar para as lacunas, ao menos no sentido mais estrito do termo (ausência, no sistema jurídico, de qualquer norma ou critério para regular uma situação). Saber se a ordem jurídica é completa ou não deixa de ser uma questão tão instigante quanto passa a ser premente o problema de como determinar o direito aplicável em um conjunto no qual múltiplas normas constantemente disputam espaço, sobrepóem-se e colidem entre si.

De todo modo, tem-se que a ascensão teórica dos princípios - a maioria, há tempos, com alguma base constitucional - teve como efeito, também, o deslocamento da questão das lacunas para a teoria da Constituição.

Miranda (2015, p. 336), p. ex., conceitua as lacunas constitucionais como "situaçôes constitucionalmente relevantes não previstas". Advoga que "a integração das lacunas de normas formalmente constitucionais deve ser feita no interior da Constituição formal e à luz dos valores da Constituição material”, observando que o reconhecimento da existência de lacunas, em última análise, é tanto maior quanto é a consciência de que o processo político encontra-se submetido ao Direito e que soluçōes idôneas demandam que se leve em conta a mutável realidade constitucional. 
Pode-se complementar com Souza Neto e Sarmento (2012), que explicam serem as lacunas da Constituição algo diferente da simples não regulação, mediante a opção política de deixar o tema a critério do legislador, bem como algo diverso do denominado silêncio eloquente, consistente em uma clara escolha de não incluir significando excluir. De acordo com os autores, as lacunas constitucionais ocorrem, primeiramente, quando inexiste norma constitucional em matéria que, da consideração global da Constituição, extrai-se que ela tenha reservado para si, sendo impossível a disciplina em sede infraconstitucional. Ainda é possível falar em lacuna da Constituição - prosseguem - na hipótese de uma situação extraordinária à qual a aplicação das normas constitucionais a princípio incidentes produziria resultados absolutamente incompatíveis com o espírito da própria Constituição.

Postas todas essas consideraçóes, é o momento de verificar como pode se situar a doutrina do devido processo legal substantivo nesse complexo panorama teórico envolvendo ordenamento jurídico, Constituição, completude/incompletude (lacunas) e (in)determinação.

Inicialmente, tem-se com Kelsen que, ainda que se admita o dogma da completude do ordenamento jurídico, isso não impede que juízes e tribunais recorram a parâmetros extrajurídicos para as suas decisóes quando, por alguma razão, o resultado da escorreita aplicaçáo do Direito positivo revele-se, para eles, indesejável.

De outro modo, reconhecendo-se a incompletude formal (lógica) do ordenamento, como faz Bobbio, igualmente se conclui que, ao menos para determinados casos - as lacunas (no sentido técnico) - critérios exteriores ao sistema têm de ser adotados. O filósofo italiano destaca, de mais a mais, a possibilidade de existirem lacunas ideológicas, situaçóes nas quais o extrajurídico - jurídico, aqui, entendido no sentido positivista - usualmente é manejado para conduzir a aplicação do Direito.

Em Engish e Perelman observam-se desenvolvimentos adicionais na relação Direito positivo-extrajurídico, para além das noçôes de correspondência/incompatibilidade, passando-se a enfocar, também, a abertura do Direito a critérios valorativos, a influência da interpretação na aplicação do Direito e na relação Direito-moral e os mecanismos de racionalização desses processos. 
O que é de destacar, neste ponto, é que, independentemente da completude ou incompletude da ordem jurídica, é inevitável que possam existir situaçôes em que o Direito positivo não será aplicado a partir de elementos internos, cabendo aos teóricos do Direito, então, a identificação dos critérios aplicáveis e a definição dos parâmetros da sua incidência.

Com a superação do modelo de regras, a importância dessas tarefas foi sobremaneira reforçada, especialmente ante o problema da (in)determinabilidade do Direito. Nas teorias ditas pós-positivistas ou não positivistas, a propósito, alguns elementos tradicionalmente entendidos como extrajurídicos pelos positivistas, a exemplo da moral, passaram a ter lugar, ainda que parcialmente, naquilo que se compreende como o fenômeno jurídico (ALEXY, 2014).

Quando se passa à questão das lacunas em termos constitucionais, o que pode ser observado, em primeiro lugar, é que a sua identificação, antes de tudo, requer a atividade interpretativa em torno de normas de conteúdo político; requer, assim, a formulação de juízos de valor. Isso torna um tanto quanto difícil distinguir, na prática, as lacunas em sentido estrito das lacunas definidas por Bobbio como ideológicas.

Em vista da ascensão teórica dos princípios, boa parte deles gozando de estatura constitucional, aliada aos paradigmas pós-positivistas de aplicação do Direito, resta igualmente dificultosa a distinçáo entre casos de lacunas constitucionais e casos de indeterminação do Direito, assim como a diferenciação dos métodos de resposta a tais conjecturas, cabendo realçar, neste ponto, a referência dos constitucionalistas a critérios materiais, ao espírito da Constituição e à mutável realidade constitucional.

O que parece remanescer como certo nesse cenário é:

(i) a possibilidade de existirem lacunas axiológicas (valorativas), quer dizer, quando um caso está correlacionado por um sistema normativo com uma determinada solução e há uma propriedade que é tida como irrelevante para esse caso de acordo com esse sistema, embora devesse ser relevante em virtude de certos padrôes axiológicos (NINO, 2010); e 
(ii) tratar-se a Constituição de um sistema normativo aberto de regras e princípios, dinâmico e dotado de capacidade de aprendizagem para captar mudanças da realidade e das concepçóes cambiantes da verdade e da Justiça (CANOTILHO, 2003).

Dadas essas premissas, a despeito das críticas que se dirigem à doutrina, vislumbra-se haver pertinência na ideia de devido processo legal substantivo tanto em uma concepção que advogue a completude do ordenamento jurídico como numa visão de incompletude, e independente do problema da (in)determinação do Direito.

Ocorre que a doutrina do substantive due process foi concebida como um mecanismo de limitação do poder, cujos atos podem vir a subverter os padróes axiológicos, padróes esses que não são estáticos; mudam no tempo e no espaço.

Com esse desiderato, a doutrina ajusta-se a ordenamentos tidos como completos ou incompletos. E pode ser empregada para obstar que a indeterminação do Direito seja aproveitada como pretexto para a criação de situaçóes arbitrárias ou desarrazoadas. Ao mesmo tempo, pode auxiliar talvez não na determinação, mas, certamente, na busca do correto, do justo.

A explicitação da razáo de ser da doutrina - evitar a subversão dos padróes axiológicos - serve para mostrar, outrossim, não se tratar, absolutamente, de uma fórmula vazia, pois não pode ser totalmente vazio algo claramente concebido para uma determinada finalidade. $\mathrm{E}$, de resto, é da própria essência da doutrina ter uma parcela de conteúdo cambiante em consonância com o curso histórico e as variaçóes culturais.

Quando o substantive due process é aplicado, paralisando um ato estatal arbitrário ou desarrazoado, é natural - necessário - que ocorra a substituição de uma valoração legislativa ou administrativa, dado que a manutenção de tal valoração justamente levaria ao resultado danoso que almeja evitar.

A suposta ausência de limites definidos ou definíveis ao controle judicial não é um problema exclusivo da doutrina do devido processo legal substantivo (tal crítica pode ser dirigida a qualquer doutrina envolvendo um conceito jurídico aberto - a 
doutrina do abuso de direito, v.g.) e, no caso dela, ignora o caráter essencialmente cambiante do seu conteúdo e a possibilidade, a despeito disso, de desenvolver um capital teórico acumulado.

De outro lado, a colegialidade e a composição representativa do poder Legislativo não se mostraram suficientes para proteger os cidadáos contra arbitrariedades, mostrando-se certo que, bem lembra Bobbio (1995), "se o legislador abusa do seu poder, toda a sociedade se ressentirá disto".

No Direito brasileiro, em que pese se tenha uma Constituição analítica e dotada de um catálogo aberto de direitos, com as exigências de razoabilidade e proporcionalidade podendo ser extraídas de outros princípios - o que pode dar uma impressáo de completude da ordem jurídica - a doutrina do devido processo legal substantivo também encontra espaço, ainda que em caráter subsidiário, dada a imprevisibilidade do surgimento e da feiçấo das lacunas axiológicas, bem como na condiçẫo de instrumento de reforço da proteção dos cidadãos contra investidas arbitrárias do poder público.

\section{CONSIDERAÇÕES FINAIS}

A doutrina do devido processo legal substantivo é uma teorização que se desenvolveu à revelia de uma previsão legislativa, sendo concebida por juristas e abraçada pela jurisprudência. Inicialmente nos Estados Unidos da América, encontrando aceitação, também, no Brasil, ainda que com notas diversas.

$\mathrm{O}$ advento da doutrina não decorreu da incompletude formal ou lógica da ordem jurídica, ou de alguma deficiência intrínseca a ela. Na suposição teórica da completude do ordenamento, também haveria espaço para o florescimento do devido processo substantivo.

O substantive due process surgiu como instrumento de limitação do poder Legislativo, emergindo como mecanismo necessário para obstar atos arbitrários ou desarrazoados, os quais podem ser enquadrados como lacunas - no sentido figurado do termo - ideológicas ou axiológicas. 
As questóes trazidas pelo pós-positivismo, ou pelas teorias não positivistas, incluindo o problema da (in)determinação do Direito, assim como a teoria constitucional contemporânea, antes de infirmarem a viabilidade da doutrina do devido processo substantivo, parecem ser, na verdade, de certa forma, ao mesmo tempo a comprovaçáo do acerto e o desenvolvimento, agora deveras refinado, daquela teorizaçáo que despontou na segunda metade do século 19. O substantive due process, nesse prisma, permanece como fundamento idôneo para guiar o pensamento jurídico, inclusive na realidade brasileira.

\section{REFERÊNCIAS}

ALEXY, R. O conceito e a natureza do direito. Tradução Thomas da Rosa de Bustamante. São Paulo: Marcial Pons, 2014. (Tradução de El concepto y la naturaleza del derecho).

. Teoria dos direitos fundamentais. Tradução Virgílio Afonso da Silva. 2. ed. São Paulo: Malheiros, 2011. (Tradução da 5a edição alemã de Theorie der Grundrechte).

BARROSO, L. R. Curso de direito constitucional contemporâneo: os conceitos fundamentais e a construção do novo modelo. 4. ed. São Paulo: Saraiva, 2013.

. Os princípios da razoabilidade e da proporcionalidade no direito constitucional. Revista Forense, Rio de Janeiro, v. 336, p. 125-136, out./dez. 1996.

BOBBIO, N. O positivismo jurídico: liçôes de filosofia do direito. Compiladas por Nello Morra. Tradução e notas Márcio Pugliesi, Edson Bini, Carlos E. Rodrigues. São Paulo: Ícone, 1995.

- Teoria do ordenamento jurídico. Tradução Maria Celeste Cordeiro Leite dos Santos.

10. ed. Brasília: Ed. Universidade de Brasília, 1999. Título original: Teoria dell'ordinamento giuridico.

BRASIL. Supremo Tribunal Federal. Ações diretas de inconstitucionalidade no 173 e 394. Relator ministro Joaquim Barbosa. Brasília, 25 de setembro de 2008. Diário da Justiça Eletrônico de 20 de março de 2009.

CANOTILHO, J. J. G. Direito constitucional e teoria da constituição. 7. ed. Coimbra: Almedina, 2003.

DWORKIN, R. Levando os direitos a sério. Tradução e notas Nelson Boeira. São Paulo: Martins Fontes, 2002. (Título original: Taking rights seriously).

ELY, J. H. Democracia e desconfiança: uma teoria do controle judicial de constitucionalidade. Tradução Juliana Lemos. São Paulo: WMP Martins Fontes, 2010. Título original: Democracy and distrust: a theory of judicial review. 
ENGISH, K. Introdução ao pensamento jurídico. Tradução J. Baptista Machado. 11. ed. Lisboa: Fundação Calouste Gulbenkian, 2014. (Tradução do original alemão intitulado: Einführung in das juristische denken, 8. neu bearb. Auflage, 1983).

FERREIRA FILHO, M. G. Direitos humanos fundamentais. 15. ed. São Paulo: Saraiva, 2016. KELSEN, H. Teoria geral do direito e do Estado. Tradução Luís Carlos Borges. 4. ed. São Paulo: Martins Fontes, 2005. (Título original General theory of law and state).

. Teoria Pura do Direito. Tradução João Baptista Machado. 6. ed. São Paulo: Martins Fontes, 1998. Título original Reine Rechtslehre.

MARINONI, L. G.; MITIDIERO, D. Direitos fundamentais processuais. In: SARLET, I. W.; MARINONI, L. G.; MITIDIERO, D. Curso de direito constitucional. 2. ed. São Paulo: Revista dos Tribunais, 2013. p. 699-766.

MARIOTTI, A. Princípio do devido processo legal. Porto Alegre. 2008. Tese (Doutorado em Direito) - Universidade Federal do Rio Grande do Sul, 2008.

MATTOS, S. L. W. A funcionalidade do devido processo legal: devido processo substantivo e justo processo civil na Constituição da República Federativa do Brasil de 1988. 2008. Tese (Doutorado em Direito) - Universidade Federal do Rio Grande do Sul, Porto Alegre, 2008.

MENDES, G. F. O princípio da proporcionalidade. In: MENDES, G. F.; BRANCO, P. G. G. Curso de direito constitucional. 8. ed. São Paulo: Saraiva, 2013. p. 217-233.

MIRANDA, J. Teoria do Estado e da Constituição. 4. ed. Rio de Janeiro: Forense, 2015.

NINO, C. S. Introdução à análise do direito. Tradução Elza Maria Gasparotto. Revisão da tradução Denise Matos Mariano. São Paulo: Ed. WMF Martins Fontes, 2010. (Título original Introducción al análise del derecho).

PEREIRA, S. T. A doutrina norte-americana do devido processo substantivo (substantive due process). 2006. Dissertação (Mestrado em Ciência Jurídica) - Universidade do Vale do Itajaí, Itajaí, 2006.

PERELMAN, C. Ética e direito. Tradução Maria Ermantina de Almeida Prado Galvão. 2. ed. São Paulo: Martins Fontes, 2005. (Obra originalmente publicada em francês com o título Éthique et droit, por Éditions de l'Université de Bruxelles, em 1990).

SOUZA NETO, C. P.; SARMENTO, D. Direito constitucional: teoria, história e métodos de trabalho. Belo Horizonte: Fórum, 2012.

STRECK, L. L. Verdade e consenso: Constituição, hermenêutica e teorias discursivas. 5. ed. São Paulo: Saraiva, 2014. 